\title{
Engineering solutions in the construction of production facilities for waste processing
}

\author{
Ariadna Kirillova ${ }^{1, *}$, Vladimir Zotov ${ }^{2}$ and Nina Musinova ${ }^{3}$ \\ ${ }^{1}$ Moscow State University of Civil Engineering, 26, Yaroslavskoye Shosse, 129337, Moscow, Russia \\ ${ }^{2}$ State University of management, Moscow, Ryazansky prospect, 99, 109542, Moscow, Russia \\ ${ }^{3}$ Financial University under the Government of the Russian Federation, Leningrad prospect, 51, \\ 125993, Moscow, Russia
}

\begin{abstract}
The article discusses the features of engineering solutions in the construction of facilities for the processing of waste, including construction management of temporary waste storage, waste treatment and incineration plants with the provision of recycling or disposal of residual waste. When developing the design solutions one should consider the availability of existing facilities at large industrial enterprises and the possibility of creation on their basis of major regional recycling centres; the factors of production specialization and cooperation development in the implementation of investment projects; creation of industrial parks, specializing in the processing of solid waste. The article describes the main indicators of the construction of a plant for the thermal treatment of municipal solid waste. The authors consider the advantages of such projects, resulting in reduction of volume of disposed solid waste by $70-80 \%$, the possibility of building objects close to the places of waste generation and reduction of transportation routes, environmental safety of plants with proper maintenance, creating a comfortable environment and enhancing the quality of life of the population.
\end{abstract}

\section{Introduction}

Solution of tasks to modernize waste management involves developing the long-term target investment programs for construction of waste recycling facilities. Structural analysis of the problems of contamination of natural areas and disposal of waste determines the score of the negative impact of economic development, the volume of the contaminants causing damage, disorder of the control system, lack of elaboration of the technological forecasts and justifies the development of organizational and economic mechanisms to ensure optimal reproductive potential of nature organizations, the need for education $[1,2]$.

Investments in fixed capital aimed at environmental protection and rational use of natural resources in Russia are presented in Table 1 [3].

\footnotetext{
* Corresponding author: angela-1309.m@yandex.ru
} 
Table 1. Investments in fixed capital aimed at environmental protection and rational use of natural resources in Russia.

\begin{tabular}{|l|c|c|c|c|c|c|}
\hline \multirow{2}{*}{ Indicators } & \multicolumn{6}{|c|}{ Years } \\
\cline { 2 - 7 } & 2010 & 2011 & 2012 & 2013 & 2014 & 2015 \\
\hline Total & 89094 & 95662 & 116546 & 123807 & 158636 & 151767 \\
\hline $\begin{array}{l}\text { among them: } \\
\text { - water resources } \\
\text { protection }\end{array}$ & 46025 & 46610 & 52420 & 59505 & 76315 & 78941 \\
\hline $\begin{array}{l}\text { - land protection } \\
\text { - air protection }\end{array}$ & 26127 & 27882 & 34626 & 41196 & 55587 & 40120 \\
\hline
\end{tabular}

At the present stage investing in the implementation of modern technological processes of waste processing and significant operational costs for construction, along with measures of state support and subsidies require borrowings private investment and choose the most effective concession model of public-private partnerships (PPP) or public-municipal partnership (PMP). The current legislation adequately regulates the processes of initiating, designing concession agreements, performance evaluation, decision-making and selection of private investor for PPP project or PMP. [4]

In this regard, the challenge is to develop organizational-economic mechanism of projects implementation of engineering solutions for the construction of waste treatment plants with justification of the model of investment and system of regulation of tariff policy. Thus the conclusion of the concession contracts should be based on the approved regional standards for waste accumulation.

\section{Method and algorithm}

System engineering and technical solutions on creation of capacities on processing waste should include the construction management of temporary waste disposal, recycling and incineration with provision of recycling or disposal of residual waste. Decision on selection of projects of construction of waste recycling and incineration plants should be made only on the basis of a systematic approach and assessing the effectiveness of ongoing projects, including analysis of alternative options and possible risks. The set of methods of a substantiation and choice of effective technological solutions may include the estimation of efficiency of realisation of investment construction projects for specific construction projects, multi-criteria analysis of clusters for the processing, recycling and neutralization of wastes of production and consumption, risk analysis and assessment of the impact on the environment and the population. [5]

A comparison of the effectiveness and impact on the environment incineration (with energy recovery or heat) and waste treatment plants, the resulting residual waste and alternative options for compression and temporary (to create the infrastructure for sorting and recycling) disposal should be in the first place.

To assess the effectiveness of implementation of investment construction projects of specific objects known to apply a list of indicators including net income and discounted, internal rate of return, payback period, and calculation of break even of the project to account for risk and uncertainty arise throughout the life cycle of the project. [6, 7]

Risk management is aimed at maintaining acceptable levels of risk and to determine priority areas for implementation of regional programs and projects in the field of waste 
management, effective use of financial resources in projects of construction of factories, which provide the level of security of residence, to comprehensively consider all types of risk to the environment and population.

When developing the design solutions should consider: the availability of existing facilities at large industrial enterprises and based on them the creation of large regional recycling centres; consideration of the factors of production specialization and cooperation development in the implementation of investment projects; creation of industrial parks, specializing in the processing of solid waste.

\section{Discussion and outcomes}

The proposed approach considers the main indicators of the construction of a plant for thermal waste treatment on the example of Moscow region [8,9]. Figure 1 in the "engineering solutions" presents the general production process scheme of processing of waste with the allocation of waste treatment and incineration plants (plants for the thermal treatment of waste).

The basic indicators of the construction of a plant for the thermal treatment of municipal solid waste (MSW):

- processing capacity of MSW - 700 thousand tons per year,

- power of electricity - $65 \mathrm{MW}$,

- capital expenditure - 25 billion RUB,

- construction period - 3 years,

- useful life cycle - 30 years.

- The original conditions of the project implementation were identified as follows:

- the tariff for the admission of MSW in 2019 - 1677 rubles per ton,

- price of electricity - $1.5 \mathrm{RUB} / \mathrm{KW}^{*} \mathrm{~h}$,

- payback period - 15 years,

- basic level of capacity payment: $6000 \mathrm{RUB} / \mathrm{KW} / \mathrm{month}$,

- internal rate of return - $11 \%$.

Revenue structure of a plant for thermal waste treatment can be: capacity charges - $57 \%$, fee for reception of waste $-17 \%$, fee for electricity $-11 \%$, regional tax benefits $-15 \%$. High investment costs are partly compensated by the possibility of sales of electricity and heat, the return on investment is provided through tariffs sales of electricity and thermal energy [11]. And can also be considered a proposal to impose so-called "green tariff", i.e. high tariff for energy from MSW as a renewable energy source.

The period of construction of such a plant is 3 years at full power, using the existing mixed waste stream without pre-sorting. Preliminary calculations show that the construction of 5 plants with a capacity of 700 thousand tons of MSW per year in 2015 to 2018 can provide reduction of volume of disposed MSW in the Moscow region by 35\%. 
The strategy of industrial development

for processing, recycling and neutralization of wastes of production and consumption
Strategy of priority development of alternative projects process engineering waste recycling

THE MECHANISM FOR THE IMPLEMENTATION OF A WASTE MANAGEMENT

Structure problems

in the field of waste management

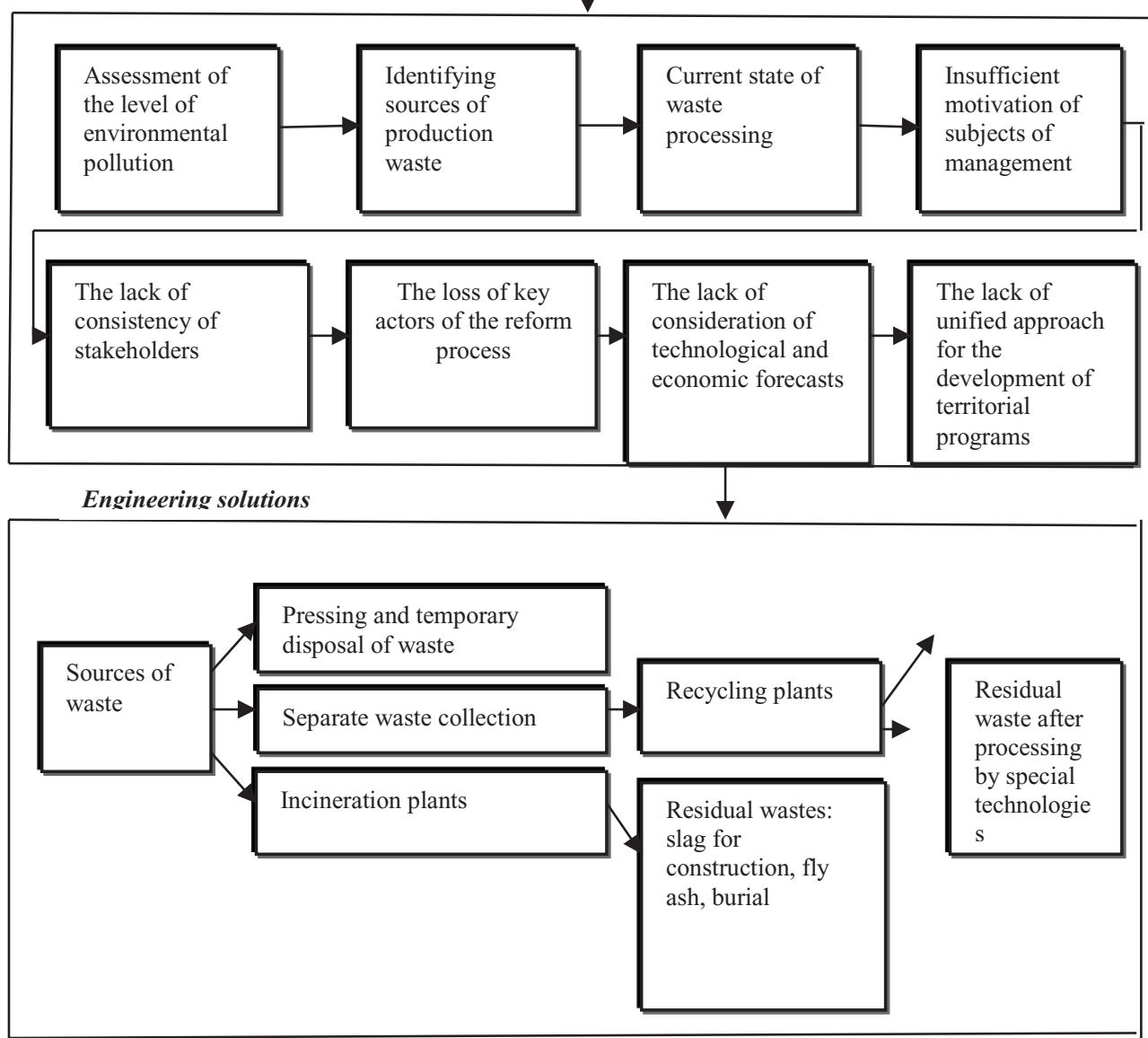

Structural implementation of activities

in the field of waste management

\begin{tabular}{|l|l|l|l|}
\hline $\begin{array}{l}\text { Organization } \\
\text { mechanism }\end{array}$ & $\begin{array}{l}\text { Economic } \\
\text { mechanism }\end{array}$ & Legal \\
mechanism & $\begin{array}{l}\text { Information } \\
\text { mechanism }\end{array}$ \\
\hline
\end{tabular}

Comparative assessment of public and socio-economic efficiency of implementation of projects and programmes, and assessment of the impact on the environment

Fig. 1. Structural scheme of development of the sphere of waste management. 


\section{Conclusions}

Thus, one of the most effective engineering solutions for the construction of facilities for waste treatment can be the projects of construction of plants for thermal recycling. The benefits of such projects are to reduce the volume of disposed solid waste by $70-80 \%$, the possibility of building objects close to the places of waste generation, and reduce transport environmental safety of plants with proper maintenance. The construction of plants is especially important in the current environment, the lack of introduction of separate collection of solid waste, Implementation of projects of construction of plants for thermal waste treatment will be not only a means for profit developers and will influence the growth of revenues of regional and municipal budgets, will qualitatively improve the living conditions of citizens, especially those living in places of temporary waste disposal and will contribute to a comfortable environment.

\section{References}

1. G. Akhmetova, Proceedings of the III International scientific-practical conference. Moscow, 9-10 (2015)

2. V. Kartsev, N. Musinova, Economics and entrepreneurship 9-2(86-2), 178-181 (2017)

3. A. Kirillova , N. Musinova, Economy and entrepreneurship 9-3(86-3), 788-791 (2017)

4. A. Kirillova, N. Musinova, Economics and entrepreneurship 10-3(86-3) (2017)

5. E. Magaril, M. Bereznyuk, V. Rukavishnikov, Environmental Economics: an interdisciplinary approach. Tutorial (Moscow, University book, 2016)

6. An. Mottaeva, As. Mottaeva, Economy and entrepreneurship 3-2 (56-2), 98-102 (2015)

7. An. Mottaeva, Oil, gas and business 2, 6-8 (2011)

8. A. Igoshev, V. Gray, O. Mednikov, V. Kazakov, Competitiveness in the global world: economics, science. Technology 2(1), 98-101 (2017)

9. A. Igoshev, V. Gray, O. Mednikov, S. Marinin, Competitiveness in the global world: economics, science. Technology 2(1), 102-106 (2017)

10. T. Verminskaya, V. Zinatullin, A. Kukhta, I. Rubtsov, E. Chibisova, Almanac of modern science and education 7, 37-39 (2008)

11. V. Lukinov, A. Mottayeva, Online magazine of science 2 (21), 54 (2014) 